\title{
Arbuscular mycorrhizal fungal communities in soils under three phytophysiognomies of the Brazilian Atlantic Forest
}

\author{
Lorrane Marques Duarte ${ }^{1}$ (D), Simone Cristina Braga Bertini ${ }^{1}$ (D), Sidney Luiz Stürmer ${ }^{2}$ (D), \\ Marcio Rodrigues Lambais ${ }^{3}$ (1) and Lucas Carvalho Basilio Azevedo ${ }^{1 *}$ (1)
}

Received: June 30, 2018

Accepted: September 5, 2018

\begin{abstract}
Arbuscular mycorrhizal fungi (AMF) play an important role in plant community productivity and structure, and so studying the factors that affect the diversity and structure of this fungal community is important for understanding their ecology in tropical forests. We investigated AMF spore communities and root colonization under three forest phytophysiognomies (Restinga Forest, REF; Lowland Ombrophilous Dense Forest, LLF; and Montane Ombrophilous Dense Forest, MTF). Spore abundance was lowest in LLF and highest in REF, with no statistical differences relative to MTF. Spore diversity indices and root colonization rates were not statistically different among the phytophysiognomies. However, principal components analysis revealed that AMF community structure differed according to forest phytophysiognomy. Hierarchical partitioning analysis indicated that most of the AMF community variables were better explained by phytophysiognomy than by chemical and physical attributes of the soil. In addition to the plant community, clay content, $\mathrm{pH}$, Boron, $\mathrm{P}, \mathrm{S}$ and $\mathrm{CEC}$ best explained some of the AMF community variables. Thus, we conclude that while several factors determine AMF community structure in the Atlantic Forest, phytophysiognomy is the most significant.
\end{abstract}

Keywords: arbuscular mycorrhiza, Glomeromycotina, hierarchical partitioning, plant community, soil attributes, soil microbiology, tropical rain forest

\section{Introduction}

The Atlantic Forest of Brazil is a hot spot of biological diversity with high levels of endemism. However, this biome has been threatened by historical deforestation for agriculture and urban development (Mittermeier et al. 1998; Myers et al. 2000). It has been estimated that only $11 \%$ to $16 \%$ of the original area $(1.29106 \mathrm{~km} 2)$ remains (Morellato \& Haddad 2000; Ribeiro et al. 2009), and consequent losses in biodiversity and ecosystem function are unquestionable (Myers et al. 2000).
Losses in biodiversity are mainly observed in plants and animals (Myers et al. 2000). Conversely, little is known about the effects of anthropic activities on microbial diversity in this biome. Recent findings on the bacterial communities of the phyllosphere, dermosphere and rhizospheric soil in the Atlantic Forest show high levels of bacterial diversity associated with specific tree species and highly similar bacterial communities within individual plants of the same taxon, suggesting that each plant species has its own microbiome (Lambais et al. 2014).

Among various plant-microbe associations, Arbuscular mycorrhiza (AM) play an important role in the shaping

1 Instituto de Ciências Agrárias, Universidade Federal de Uberlândia, 38400-902, Uberlândia, MG, Brazil

2 Departamento de Ciências Naturais, Universidade Regional de Blumenau, 89030-903, Blumenau, SC, Brazil

3 Departamento de Ciência do Solo, Escola Superior de Agricultura “Luiz de Queiroz", Universidade de São Paulo, 13418-900, Piracicaba, SP, Brazil

*Corresponding author: lucasazevedo@ufu.br 
and functioning of an ecosystem (Heijden et al. 1998; Rillig \& Mummey 2006; Smith \& Read 2008). Arbuscular mycorrhizal fungi (AMF, phylum Glomeromycotina) can develop symbiotic relationships with most known plant species (Smith \& Read 2008; Spatafora et al. 2016). The most prominent consequence of this relationship is enhanced phosphate uptake from the soil solution and transfer to plants. AM may also increase plant productivity and diversity, and drive plant community structure (Heijden et al. 1998; Klironomos et al. 2011; Garcia de León et al. 2016). In addition, the external mycelia of AMF may increase soil aggregation and carbon stock in the soil (Rillig \& Mummey 2006).

Several interdependent environmental variables, including edaphic and climatic factors, influence AMF community structure (Antunes et al. 2011; Davison et al. 2011; León et al., 2016). The structure of the plant community may also affect the AMF community. Certain plant species may create species-specific soil attributes, microclimates and associations with AMF species (Johnson et al. 1992; Mummey \& Rillig 2006). Thus, vegetation and soil types can be considered as drivers of AMF community structure (Oehl et al. 2010; Pagano et al. 2013; Mathimaran et al. 2005).

Studies on the tropical rain forest have focused on how different management practices and forest disturbance intensities (León et al. 2018; Pereira et al. 2018), altitudinal and ecological restoration gradients (Bonfim et al. 2016; Silva et al. 2015b), and early stages of plant succession (Stürmer et al. 2006; Zangaro et al. 2013) affect AMF community structure. The occurrence of AMF species in the Atlantic Forest has also been compiled by Jobim et al (2018). However, the effects of phytophysiognomy type on diversity of mycorrhizal fungi needs to be better clarified. Different phytophysiognomies are common in the biome and vary with altitude. Differences in plant community structure (Assis et al. 2011; Campos et al. 2011; Padgurschi et al. 2011) suggest that AMF communities may also vary by phytophysiognomy type. Therefore, quantifying the extent to which phytophysiognomy and specific soil physical and chemical variables determine AMF variables could enhance our understanding of community structure in the Atlantic Forest.

We evaluated AMF community structure, diversity, and root colonization within permanent plots in three preserved phytophysiognomies of the Atlantic Forest (Restinga Forest, Lowland Ombrophilous Dense Forest and Montane Ombrophilous Dense Forest). We examined whether AMF sporulation, community structure, diversity, and root colonization were affected by phytophysiognomy, and the physical and chemical properties of the soil. Given that edaphic climatic conditions and plant community could influence the composition of the AMF community, we hypothesized that AMF species composition is more strongly influenced by phytophysiognomy than by the physical and chemical properties of the soil.

\section{Materials and methods}

\section{Study area}

Soil and root samples were collected from permanent plots $(100 \mathrm{~m} \times 100 \mathrm{~m})$ in three phytophysiognomies of the Atlantic Forest (established using the Biota-Program from the São Paulo State Research Foundation) located in the Serra do Mar State Park, São Paulo, Brazil (Joly et al. 2012) (Fig. 1). The permanent plots were set up within a

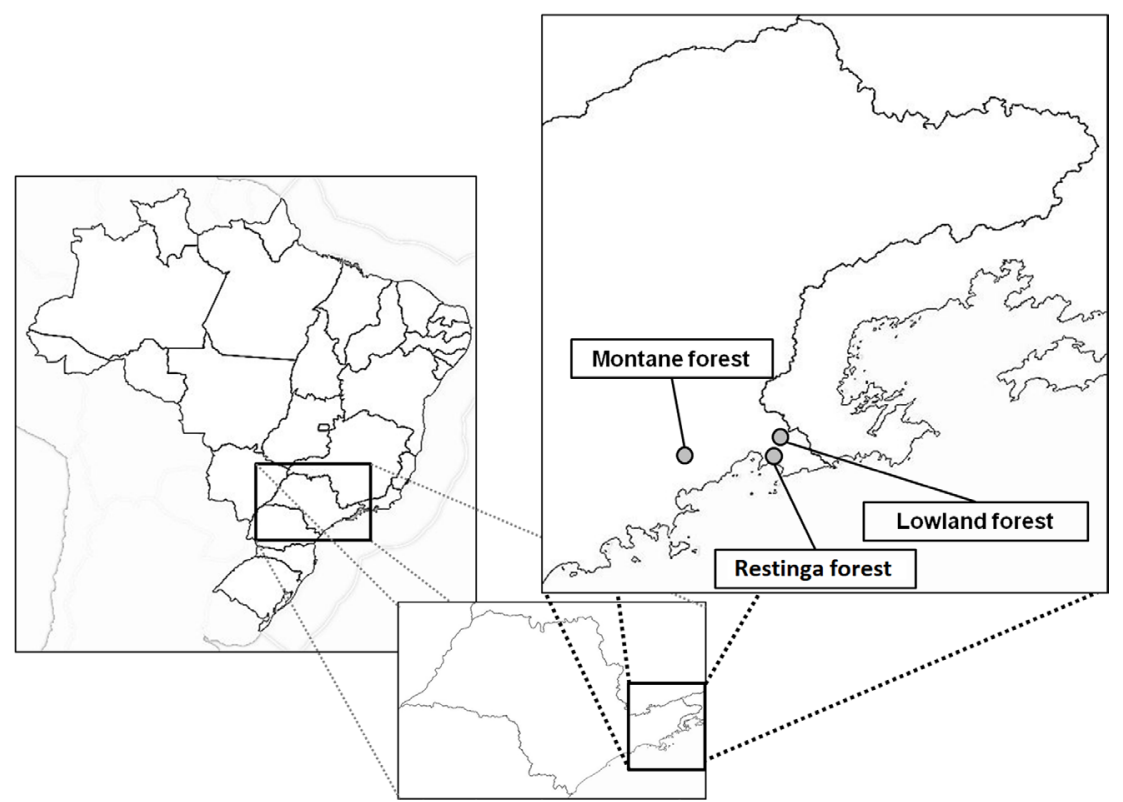

Figure 1. Study areas in Brazil were permanent plots of Restinga Forest (10 m elevation), Lowland Ombrophilous Dense Forest ( $75 \mathrm{~m}$ elevation) and Montane Ombrophilous Dense Forest (1000 m elevation) within the Serra do Mar State Park in the Atlantic Forest. 
Restinga forest (REF), (elevation 9.5 to $10.5 \mathrm{~m}, 23^{\circ} 21^{\prime} 22^{\prime \prime} \mathrm{S}$ $44^{\circ} 51^{\prime} 03^{\prime \prime} \mathrm{W}$ ), a Lowland Ombrophilous Dense Forest (LLF) (elevation 64 to $89 \mathrm{~m}, 23^{\circ} 20^{\prime} 05^{\prime \prime} \mathrm{S} 44^{\circ} 49^{\prime} 55^{\prime \prime} \mathrm{W}$ ), and a Montane Ombrophilous Dense Forest (MTF) (elevation 1010 to $1040 \mathrm{~m}, 23^{\circ} 20^{\prime} 36^{\prime \prime} \mathrm{S} 45^{\circ} 04^{\prime} 22^{\prime \prime} \mathrm{W}$ ). Henceforth, the Lowland Ombrophilous Dense Forest will be referred to as the "Lowland forest" and the Montane Ombrophilous Dense Forest as the "Montane forest".

The Restinga forest had Typic Quartzipsamment sandy soil that was seasonally waterlogged, acidic ( $\mathrm{pH} 3.9$ to 5.0 ) and had high $\mathrm{Al}$ saturation (approximately $57 \%$ of the cation exchange capacity (CEC)). Assis et al (2011) identified 84 plant species from 32 families in the Restinga forest plot. Myrtaceae, Arecaceae and Euphorbiaceae were the most abundant plant families and accounted for $57 \%$ of the individuals (Joly et al. 2012).

The Lowland forest featured strongly undulating relief with clayey Typic Dystrochept soil that was acidic (pH 4.1 to 4.7), had high Al saturation (averaging $55 \%$ of CEC), and was stony with outcrops of granite/gneiss. The Lowland forest plot contained 142 plant species within 41 families (Campos et al. 2011). The most abundant species were Euterpe edulis Mart., Mollinedia schottiana (Spreng.) Perkins., Bathysa mendoncaei K.Schum., Coussarea accedens Müll. Arg. and Rustia formosa (Cham. \& Schltdl.) Klotzsch. while Myrtaceae, Rubiaceae and Fabaceae were the most abundant plant families.

The Montane forest was on strongly undulating relief, with clayey Typic Dystrochept soil that was acidic ( $\mathrm{pH}$ 4.1 to 4.3 ) with high $\mathrm{Al}$ saturation (averaging $72 \%$ of $C E C$ ). Padgurschi et al. (2011) identified 149 plant species from 40 families in the Montane forest plot. The most abundant species were Euterpe edulis Mart., Licania hoehnei Pilg., Calyptranthes lucida Mart., Ocotea catharinensis Mez. and Mollinedia argyrogyna Perkins while Arecaceae, Myrtaceae, and Monimiaceae were the most abundant families.

The climate in the Restinga and Lowland forests is Tropical/Subtropical Humid (Af/Cfa, Köppen classification) with no dry season. The average annual rainfall is over $2200 \mathrm{~mm}$, while the average annual temperature is $22^{\circ} \mathrm{C}$ (Joly et al. 2012; Setzer 1966; Embrapa 2009) and the average minimum temperature is $18^{\circ} \mathrm{C}$ (measured from Sep 2006 to Nov 2007, Siegloch 2010). The climate of the Montane forest is Humid subtropical (Cwa, Köppen classification) with an average annual precipitation of $2500 \mathrm{~mm}$, average annual temperature of $21^{\circ} \mathrm{C}$ and average minimum temperature of $15^{\circ} \mathrm{C}$ (measured between Sep 2006 and Nov 2007, Siegloch 2010).

\section{Soil and root sampling}

Soil and roots were collected at the end of the dry season (October, 2011), and randomly sampled (six replicates) within each of the permanent plots in the Restinga, Lowland and Montane forests. Specifically, three subsamples (spaced equidistantly $\sim 100 \mathrm{~cm}$ ) were collected from each random point using a soil probe ( $20 \mathrm{~cm}$ depth). These subsamples were then pooled to form a single sample per point. Therefore, a total of 18 samples were collected (three phytophysiognomies $\mathrm{x}$ six replicates). The soil and root samples were placed in plastic bags and stored at $4^{\circ} \mathrm{C}$ until processing.

\section{Chemical and physical analysis of the soil}

Soil $\mathrm{pH}$ and concentrations of $\mathrm{H}+\mathrm{Al}, \mathrm{Al}, \mathrm{Ca}, \mathrm{Mg}, \mathrm{P}$, organic carbon $(\mathrm{OC}), \mathrm{K}, \mathrm{S}, \mathrm{B}, \mathrm{Cu}, \mathrm{Fe}, \mathrm{Mn}$ and $\mathrm{Zn}$ were determined according to Silva (2009). CEC, base saturation and $\mathrm{Ca}, \mathrm{Mg}, \mathrm{K}$ and $\mathrm{Al}$ saturation of $\mathrm{CEC}$ were calculated as: $\mathrm{CEC}=(\mathrm{Ca}+\mathrm{Mg}+\mathrm{K}+\mathrm{Al}+\mathrm{H})$; base saturation $=(\mathrm{Ca}+\mathrm{Mg}+\mathrm{K} /$ $\mathrm{CEC})^{*} 100 ; \mathrm{Ca}, \mathrm{Mg}$ and $\mathrm{K}$ saturation $=[(\mathrm{Ca}$ or $\mathrm{Mg}$ or $\mathrm{K}) /$ $\mathrm{CEC}]^{*} 100$; Al saturation $=[\mathrm{Al} /(\mathrm{Ca}+\mathrm{Mg}+\mathrm{K}+\mathrm{Al})]^{*} 100$. Soil texture was determined accordingly to Gee \& Or (2002).

\section{Arbuscular mycorrhizal fungi spores: counts, richness and diversity estimations}

AMF spores were extracted from $50 \mathrm{~g}$ of soil by wet sieving (Gerdemann \& Nicolson 1963) and centrifugation in water and in a $70 \%$ sucrose solution. The spores were rinsed in tap water and collected with a $38 \mu \mathrm{m}$ mesh sieve. The spores were then mounted on glass slides using polyvinyl-lacto-glycerol (PVLG) and PVLG with Melzer's reagent $(1: 1, v / v)$ for identification and then separated by morphotype. AMF spores were identified at the genus/ species level according to Schenck \& Pérez (1990) and using morphological descriptions from the INVAM website (http://invam.cav.wvu.edu) and Glomeromycotina species list website (http://www.lrz.de/ schuessler/amphylo/).

The frequency of occurrence of each AMF species was calculated as the percentage of samples in which a species was observed. Species richness was estimated as the number of species observed in each treatment using the non-parametric estimators ACE (Chao \& Lee 1992) and CHAO-1 (Chao 1984) determined using the SPADE program (Chao \& Shen 2010). The Shannon diversity index and the reciprocal of the Simpson index were calculated using AMF spore abundance. The Pielou index of equitability was determined as described by Magurran (1988).

\section{Root colonization}

Roots were randomly separated from the soil samples using tweezers ( $1 \mathrm{~g}$ from each soil sample), rinsed in tap water to eliminate soil debris, immersed for 15 hours in $10 \% \mathrm{KOH}$ solution at room temperature and then clarified in a water bath at $60^{\circ} \mathrm{C}$ for $10 \mathrm{~min}$. After discarding the $\mathrm{KOH}$ solution, the roots were washed with tap water, immersed in $\mathrm{HCl} 1 \%$ solution and then stained ( $5 \%$ Parker blue pen ink, $5 \%$ acetic acid and $10 \%$ lactic-glycerol) (Vierheilig et al. 
1998) for three min at $90^{\circ} \mathrm{C}$. Mycorrhizal root colonization was measured under a dissecting microscope using the grid-line intersect method (Giovannetti \& Mosse 1980).

\section{Statistical analysis}

Variables were tested for homogeneity of variance (Bartlett test) and normality (Shapiro Francia and Lilliefors (Kolmogorov-Smirnov)). Spore counts were transformed to $(x+0.5)^{0.5}$ and root colonization data were normalized using $\arcsin (\mathrm{x})^{0.5}$. ANOVA was used when the assumptions for the parametric tests were met, while the Kruskal-Wallis test $(p<0.05)$ was employed when the normality and homoscedasticity assumptions were not met. ANOVA was conducted using the PROC GLM procedure in SAS 9.2 (Littell et al. 2006) and the Kruskal-Wallis test was performed using R software (RStudio, Boston, MA). The means from the normal data were compared using the Tukey Kramer test $(\mathrm{p}<0.05)$ (SAS version 9.2; SAS Institute, Cary, NC).

Principal component analysis (PCA) was used to visualize relationships among AMF species, biological variables (diversity indexes, spore counts and root colonization), and associations with soil physical and chemical properties, and to determine whether the samples could be differentiated by phytophysiognomy (Lepš \& Šmilauer 2003). PCA was performed with a focus on inter-species correlations (Lepš \& Šmilauer 2003) and using Canoco software version 4.5 (Biometris, Netherlands).

Hierarchical Partitioning analysis (HP) was performed as in Bertini et al. (2014) ("hier.part" package version 1.04, Walsh \& Mac Nally 2015, and implemented using the R software, R Development Core Team 2017) to estimate the percent of total variation in spore number, root colonization, AMF species and diversity variables explained by a given environmental variable (phytophysiognomy, physical and chemical soil properties) (Chevan \& Sutherland 1991; Mac Nally 2000; Mac Nally \& Walsh 2004). Thus, the environmental variables or predictor variables consisted of categories (phytophysiognomy), physical soil properties and chemical soil properties. Multicollinearity between predictor variables was determined using the 'car' package of R software. Variables with Variance Inflation Factors (VIFs) $>5$ and Tolerance $<0.2$ were considered collinear and not used to construct the models (Montgomery \& Peck 1992). All independent effect/joint effect ratios of predictor variable were higher than 1.0, which indicates low collinearity among predictor variables (Mac Nally 2000; Pont et al. 2005; Arenas et al. 2006). R-squared was used as the goodness-of-fit measure. Generalized linear models (GLMs) were used for response variables that did not meet the assumptions of the linear regression model (i.e. goodness-of-fit argument "Rsqu" and family argument of glm "gaussian") (Millington et al. 2007; Walsh \& Mac Nally 2015). The statistical significance of the independent contributions of each environmental variable was accepted at the upper $95 \%$ confidence limit ( $\mathrm{Z}$ score $\geq 1.65$ ) and determined using a randomization approach with 100 interactions (Mac Nally 2000).

\section{Results}

\section{Soil physical and chemical attributes}

All soil samples were acidic ( $\mathrm{pH}$ from 4.17 to 4.50 ) and had high Al saturation ( $54.6 \%$ to $73.1 \%$ of the CEC) (Tab. 1). Some soil properties were affected by different phytophysiognomies. Ten of the nineteen soil physicochemical attributes $(\mathrm{pH}, \mathrm{Al}, \mathrm{CEC}, \mathrm{K} \%, \mathrm{Al} \%, \mathrm{Zn}, \mathrm{B}$, sand, silt and clay content) differed by phytophysiognomy type. Soil $\mathrm{pH}, \mathrm{Zn}$ level and sand content were significantly greater in the Restinga forest than in the Montane forest. Conversely, $\mathrm{Al} \%, \mathrm{Al}$ content, clay and silt content were greater in the Montane forest than in the Restinga forest. $\mathrm{CEC}$ and $\mathrm{K} \%$ were greater in the Lowland forest than in the Montane forest.

Table 1. Soil chemical and physical attributes in three phytophysiognomies (Restinga Forest - REF, Lowland Forest LLF, and Montane Forest - MTF) in the Atlantic Forest.

\begin{tabular}{|c|c|c|c|}
\hline \multirow{2}{*}{ Soil Attributes } & \multicolumn{3}{|c|}{ Phytophysiognomy } \\
\hline & REF & LLF & MTF \\
\hline $\mathrm{pH}$ & $4.50( \pm 0.3) \mathrm{A}$ & $4.37( \pm 0.2) \mathrm{AB}$ & $4.17( \pm 0.09) \mathrm{B}$ \\
\hline $\mathrm{Al}^{3+}\left(\mathrm{mmolc} \mathrm{kg}^{-1}\right)$ & $2.07( \pm 0.5) \mathrm{B}$ & $2.29( \pm 0.6) \mathrm{B}$ & $3.40( \pm 0.7) \mathrm{A}$ \\
\hline $\mathrm{H}^{+}+\mathrm{Al}^{3+}\left(\mathrm{mmolc} \mathrm{kg}^{-1}\right)$ & $5.13( \pm 0.1) \mathrm{A}$ & $5.00( \pm 0.3) \mathrm{A}$ & $4.94( \pm 0.06) \mathrm{A}$ \\
\hline CEC & $6.50( \pm 0.2) \mathrm{AB}$ & $6.65( \pm 0.3) A$ & $6.22( \pm 0.3)$ B \\
\hline $\mathrm{P}\left(\mathrm{mg} \mathrm{kg}^{-1}\right)$ & $82.5( \pm 4.5) \mathrm{A}$ & $79.6( \pm 7.0) \mathrm{A}$ & $80.6( \pm 7.0) \mathrm{A}$ \\
\hline $\mathrm{S}\left(\mathrm{mg} \mathrm{kg}^{-1}\right)$ & $69.11( \pm 18) \mathrm{A}$ & $70.9( \pm 7.3) \mathrm{A}$ & $63.6( \pm 1.7) \mathrm{A}$ \\
\hline Organic $C\left(\mathrm{~g} \mathrm{~kg}^{-1}\right)$ & $42.6( \pm 2.9) \mathrm{A}$ & $43.3( \pm 2.1) \mathrm{A}$ & $40.7( \pm 1.4) \mathrm{A}$ \\
\hline${ }^{*}$ Ca saturation $(\%)$ & $13.1( \pm 2.9) \mathrm{A}$ & $14.4( \pm 3.7) \mathrm{A}$ & $11.4( \pm 1.9) \mathrm{A}$ \\
\hline${ }^{*} \mathrm{Mg}$ saturation (\%) & $7.66( \pm 4.5) \mathrm{A}$ & $8.24( \pm 2.8) \mathrm{A}$ & $5.30( \pm 1.0) \mathrm{A}$ \\
\hline K saturation (\%) & $2.70( \pm 0.3) \mathrm{B}$ & $3.38( \pm 0.4) \mathrm{A}$ & $2.71( \pm 0.5) \mathrm{B}$ \\
\hline $\mathrm{Al}$ saturation (\%) & $57.1( \pm 9.0)$ B & $54.6( \pm 13)$ B & $73.1( \pm 5.5) \mathrm{A}$ \\
\hline $\mathrm{Zn}\left(\mathrm{mg} \mathrm{kg}^{-1}\right)$ & $2.85( \pm 0.7) \mathrm{A}$ & $2.06( \pm 0.6) \mathrm{B}$ & $1.81( \pm 0.3) \mathrm{B}$ \\
\hline $\operatorname{Mn}\left(\mathrm{mg} \mathrm{kg}^{-1}\right)$ & $2.88( \pm 1.0) \mathrm{A}$ & $5.60( \pm 6.0) \mathrm{A}$ & $4.58( \pm 2.9) \mathrm{A}$ \\
\hline $\mathrm{Cu}\left(\mathrm{mg} \mathrm{kg}^{-1}\right)$ & $0.71( \pm 0.2) \mathrm{A}$ & $0.61( \pm 0.3) \mathrm{A}$ & $0.56( \pm 0.3) \mathrm{A}$ \\
\hline $\mathrm{Fe}\left(\mathrm{mg} \mathrm{kg}^{-1}\right)$ & $392( \pm 174) \mathrm{A}$ & $385( \pm 134) \mathrm{A}$ & $269( \pm 71) \mathrm{A}$ \\
\hline $\mathrm{B}\left(\mathrm{mg} \mathrm{kg}^{-1}\right)$ & $70.8( \pm 10) A B$ & $64.3( \pm 6.9)$ B & $76.0( \pm 3.0) \mathrm{A}$ \\
\hline Sand (\%) & $91.8( \pm 21) A$ & $75.6( \pm 49)$ B & $67.6( \pm 62) \mathrm{C}$ \\
\hline Clay (\%) & $5.5( \pm 21) C$ & $17.6( \pm 28)$ B & $22.3( \pm 37) \mathrm{A}$ \\
\hline Silt (\%) & $2.61( \pm 16)$ B & $6.63( \pm 30) A$ & $10( \pm 32) \mathrm{A}$ \\
\hline
\end{tabular}

Values are average \pm standard deviation $(n=6)$. Upper case letters compare the three phytophysiognomies. To normal data was used ANOVA and Tukey-Kramer test $(\mathrm{p}<0.05) .{ }^{*}$ Kruskal-Wallis was performed to non-normal data $(\mathrm{p}<0.05)$. Values followed by different letters are significantly different and indicated by bold numbers. $\mathrm{H}^{+}+\mathrm{Al}^{3+}$ (Potential acidity), CEC (Cation exchange capacity).

\section{Arbuscular mycorrhizal fungi in soil and roots}

Thirteen AMF species were identified from spores recovered in the field and assigned to Glomeraceae (38\%), 
Acaulosporaceae (46\%) and Gigasporaceae (16\%) (Fig. 2). The species with the highest relative abundance (Fig. 2) were also the most frequent species recovered: Glomus sp. 1 (243 spores; $74 \%$ frequency), Glomus sp. 3 (179 spores; $68 \%$ frequency) and Acaulospora mellea (27 spores; $47 \%$ frequency) (Fig. 3).

The average spore number was significantly lower in the Lowland forest than in the Restinga and Montane forests (Tab. 2). Root colonization was approximately $50 \%$; but as with the other diversity indices, did not differ statistically by phytophysiognomy (Tab. 2).

Table 2. Number of spores per $50 \mathrm{~g}$ of soil, root colonization (\%), average observed richness, estimated species number and diversity index of the AMF community in three phytophysiognomies (Restinga Forest REF, Lowland Forest LLF, and Montane Forest MTF) in the Atlantic forest.

\begin{tabular}{|c|c|c|c|}
\hline \multirow{2}{*}{ Biological attributes } & \multicolumn{3}{|c|}{ Phytophysiognomy } \\
\hline & REF & LLF & MTF \\
\hline Spores $50 \mathrm{~g}^{-1}$ soil & $30.5( \pm 24.1) \mathrm{A}$ & $4.17( \pm 3.6)$ B & $14.6( \pm 6.8) \mathrm{A}$ \\
\hline Root colonization (\%) & $53( \pm 0.1) A$ & $53( \pm 0.13) \mathrm{A}$ & 11) $\mathrm{A}$ \\
\hline$S_{A M F^{a}}$ & 2.66 & A & .0) $\mathrm{A}$ \\
\hline Shannon ${ }^{b}$ & 0.73 & $0.45( \pm$ & 0.6 \\
\hline & A & $1.35( \pm$ & $0.7) \mathrm{A}$ \\
\hline Even & 0.1) $\mathrm{A}$ & $0.47( \pm 0.5) \mathrm{A}$ & $0.59( \pm 0.2) \mathrm{A}$ \\
\hline & $\mathrm{A}$ & $1.16( \pm 1.4) \mathrm{A}$ & $3.05( \pm 1.9) \mathrm{A}$ \\
\hline $\mathrm{CHAO}^{\mathrm{e}}$ & $2.66( \pm 0.8) \mathrm{A}$ & $3.16( \pm 1.2) \mathrm{A}$ & $2.89( \pm 1.0) \mathrm{A}$ \\
\hline
\end{tabular}

Values are average \pm standard deviation $(\mathrm{n}=6)$. ${ }^{\mathrm{a}}$ - Species richness of AMF spores; ${ }^{b}$ - Shannon index by maximum likelihood estimator; ${ }^{c}$ - Reciprocal of the Simpson index; ${ }^{\mathrm{d}}$ - Pielou's Evenness; e - Estimator of species richness. Upper case letters compare the three phytophysiognomies. Values followed by different letters are significantly different according to the Tukey-Kramer test $(\mathrm{p}<0.05)$ and indicated by bold numbers.

\section{Influence of phytophysiognomy and soil properties on the AMF community}

Principal component analysis (PCA) of the data set showed consistent differences among the phytophysiognomy types relative to biological, physical and chemical properties of the soil (Fig. 4). The Montane forest was separated from the Lowland forest along the first axis (Fig. 4A), which explained $22.7 \%$ of data variability. The Restinga forest was separated from Montane forest along the second axis, explaining $15.6 \%$ of data variability.

Glomus sp4, Glomus sp3, Glomus sp. 2, Glomus sp1, Acaulospora foveata, Acaulospora mellea, root colonization, total spore number, Pielou evenness, Shannon, ACE-1, CHAO-1, $\mathrm{S}_{\mathrm{AMF}}, 1 / \mathrm{D}, \mathrm{P}$, Sand, $\mathrm{pH}, \mathrm{Zn}, \mathrm{S}$ and OC were positively associated with the Restinga forest, and negatively associated with the Lowland and Montane forests (Fig. 4A, B). The Lowland forest was positively associated with Scutellospora sp1, Scutellospora calospora, Acaulospora sp3, Acaulospora sp1, Rhizophagus fasciculatus, K, K\%, Cu and Mn, whereas the Montane forest was positively associated with A. tuberculata, Acaulospora sp2, Fe, B, Al, Al\%, silt and clay content. Clay was positively associated with Scutellospora sp1 and Scutellospora calospora, and negatively associated with Glomus sp3. The diversity indices (ACE-1 and $\mathrm{S}_{\mathrm{AMF}}$ ) and Acaulospora mellea were positively associated with $\mathrm{P}$ and $\mathrm{B}$. CEC was positively associated with $\mathrm{pH}, \mathrm{Mg}, \mathrm{Ca}, \mathrm{K}$, $\mathrm{OC}, \mathrm{S}$ and $\mathrm{Zn}$, and negatively associated with evenness.

\section{Contribution of individual soil properties and phytophysiognomy to AMF community determination}

Regarding physical and chemical variables, only $\mathrm{OC}$, $\mathrm{pH}, \mathrm{P}, \mathrm{B}, \mathrm{S}, \mathrm{Fe}, \mathrm{CEC}$ and clay content showed no collinearity between variables and were kept for HP analysis. HP was performed to estimate the contribution of individual soil properties and phytophysiognomy on explaining the total variation of each biological (AMF) variable.

Phytophysiognomy most explained total spore number and the occurrence of five of the thirteen AMF species (S. calospora, Acaulospora sp3, Glomus sp1, Glomus sp3 and Glomus sp4) (Tab. 3). Clay content most explained the occurrence of Scutellospora sp1, but also explained

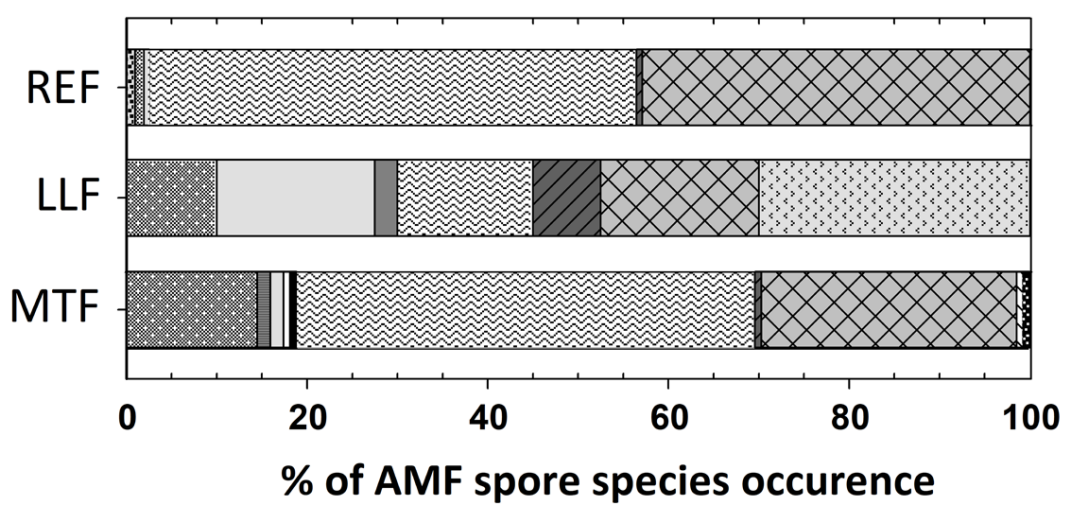

\begin{tabular}{|l|}
\hline A. foveata \\
A. mellea \\
R. fasciculatus \\
$\square$ Acaulospora sp1 \\
$\square$ Acaulospora sp2 \\
Acaulospora sp3 \\
A. tuberculata \\
Glomus sp1 \\
Glomus sp2 \\
GX Glomus sp3 \\
$\square$ Glomus sp4 \\
$\square \square$ S. calospora \\
Scutellospora sp1
\end{tabular}

Figure 2. Relative abundance of AMF species in the soil of three phytophysiognomies: Restinga Forest (REF), Lowland Ombrophilous Dense Forest (LLF) and Montane Ombrophilous Dense Forest (MTF) within the Serra do Mar State Park in the Atlantic Forest. 


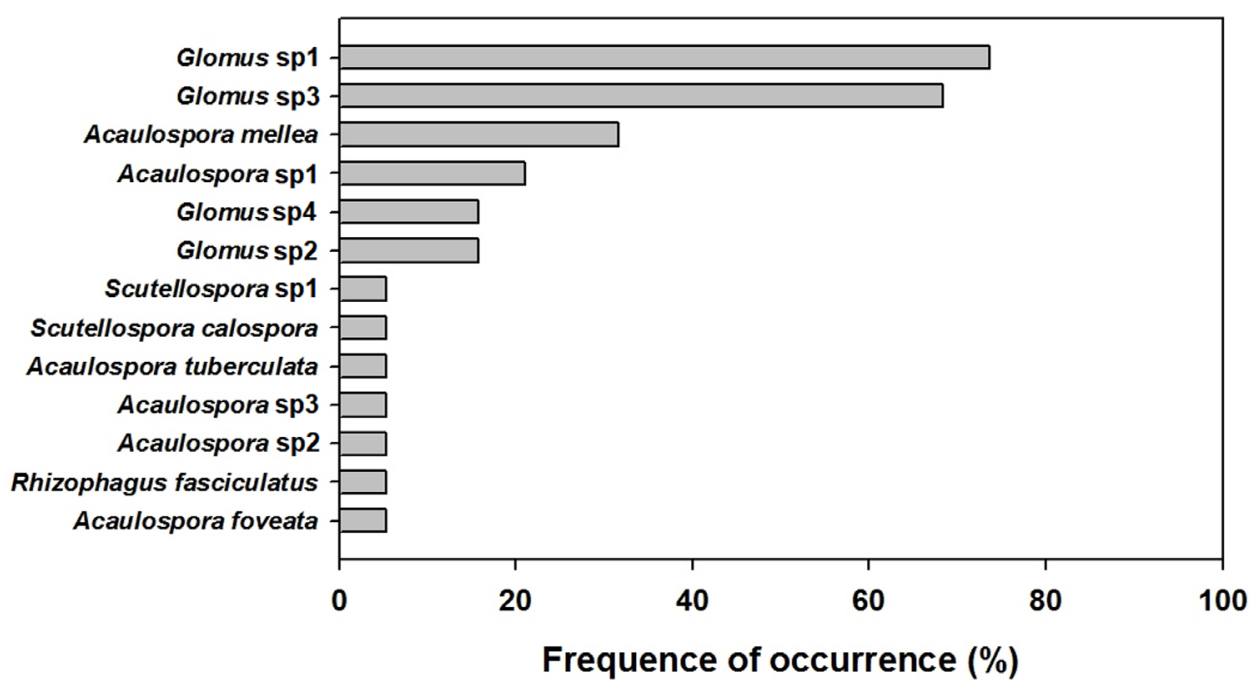

Figure 3. Frequency of occurrence of AMF species in soil samples from three phytophysiognomies: Restinga Forest (REF), Lowland Ombrophilous Dense Forest (LLF) and Montane Ombrophilous Dense Forest (MTF) within the Serra do Mar State Park in the Atlantic Forest.
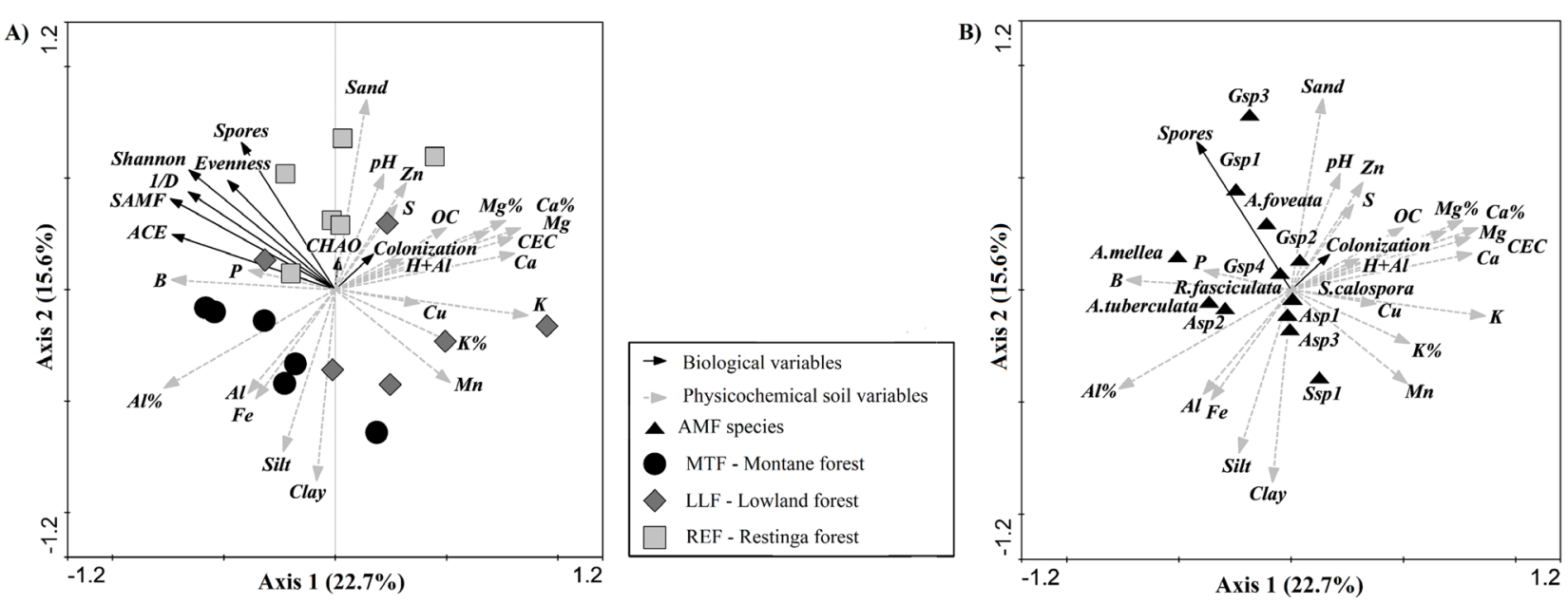

Figure 4. Principal component analysis (PCA) of spore and soil attributes with AMF species from three phytophysiognomies: Restinga Forest (REF), Lowland Ombrophilous Dense Forest (LLF) and Montane Ombrophilous Dense Forest (MTF) in permanent plots in the Atlantic Forest (Serra do Mar State Park in Ubatuba, São Paulo State, Brazil). A. Data ordinations of biological variables (diversity indexes, spore counts and root colonization), and soil physical and chemical properties with samples. B. Data ordinations of AMF species with soil physical and chemical attributes, and biological variables (spore abundance and root colonization). Axes one and two explain $38.3 \%$ of data variability, with the first axis explaining $22.7 \%$ and the second one explaining $15.6 \%$. Boro (B), Copper $(\mathrm{Cu})$, Iron (Fe), Mn (Manganese), P (Phosphorus), S (Sulfur), Zn (Zinc) = level of respective soil element; Ca \%, Mg \%, $\mathrm{K} \%$ and $\mathrm{Al} \%=$ calcium, magnesium, potassium and aluminum saturation of Cation Exchange Capacity, respectively; Colonization = root colonization level; Spores = number of AMF spores; $\mathrm{OC}=$ total organic carbon.

S. calospora, and Glomus sp3. The occurrence of A. mellea was mostly influenced by $\mathrm{P}$, while $\mathrm{CEC}$ most explained Pielou evenness. $S_{\mathrm{AMF}}$ and ACE-1 were explained mostly by $\mathrm{B}$, while $A$. foveata was best explained by $S$ content. In summary, seven of the nine explanatory variables significantly explained at least one AMF variable (Tab. 3): phytophysiognomy explained six response variables, clay content explained three, B content and $\mathrm{pH}$ explained two, while $S$, P, and CEC explained one AMF variable each.

\section{Discussion}

Influences of soil, climate and plant community on AMF communities are well-documented (Johnson et al. 1992; König et al. 2010; Oehl et al. 2010; Antunes et al. 2011). In this paper, we tested the hypothesis that phytophysiognomy is a stronger determinant of AMF community composition than soil attributes in areas of the Atlantic Forest. Our analysis indicated that multiple factors affect AMF variables; 
Table 3. Percent distribution of the independent effect (\% I) of each environmental variable (phytophysiognomy, physical and chemical soil attributes) on the variability of the arbuscular mycorrhizal fungal (AMF) community.

\begin{tabular}{|c|c|c|c|c|c|c|c|c|c|}
\hline \multirow{2}{*}{ Response variables } & \multicolumn{9}{|c|}{$\%$ Independent effects (\% I) } \\
\hline & Phytophysiognomy & $\mathbf{S}$ & $\mathrm{Fe}$ & B & pH & $\mathbf{P}$ & Org-C & CEC & Clay \\
\hline \multicolumn{10}{|l|}{ Biological variables } \\
\hline Spore number & 43.26 & 2.28 & 7.71 & 11.34 & 10.64 & 0.91 & 2.49 & 6.76 & 14.60 \\
\hline Root colonization & 14.01 & 7.34 & 2.12 & 1.46 & 41.09 & 15.86 & 8.79 & 2.97 & 6.36 \\
\hline $\mathrm{S}_{\mathrm{AMF}^{\mathrm{a}}}$ & 19.41 & 0.82 & 4.84 & 39.11 & 10.05 & 2.06 & 4.93 & 12.44 & 6.33 \\
\hline Shannon ${ }^{\mathrm{b}}$ & 12.93 & 6.37 & 4.53 & 35.21 & 2.56 & 2.72 & 5.98 & 16.92 & 12.77 \\
\hline $1 / D^{c}$ & 9.15 & 11.92 & 2.59 & 30.08 & 1.55 & 5.66 & 10.42 & 22.21 & 6.42 \\
\hline Evenness $^{\mathrm{d}}$ & 18.34 & 7.78 & 5.83 & 11.21 & 3.97 & 2.23 & 9.51 & 25.80 & 15.34 \\
\hline ACE-1 ${ }^{e}$ & 19.44 & 0.97 & 1.55 & 47.19 & 4.29 & 5.05 & 2.84 & 7.32 & 11.35 \\
\hline $\mathrm{CHAO}^{-1}{ }^{\mathrm{e}}$ & 23.11 & 16.21 & 8.42 & 0.97 & 11.04 & 2.32 & 15.96 & 10.61 & 11.37 \\
\hline \multicolumn{10}{|l|}{ AMF species } \\
\hline R. fasciculatus & 15.16 & 8.46 & 10.32 & 9.64 & 8.57 & 10.49 & 12.17 & 11.63 & 13.55 \\
\hline A. foveata & 6.23 & 41.18 & 3.78 & 1.40 & 38.13 & 0.73 & 3.02 & 0.78 & 4.74 \\
\hline A. mellea & 16.91 & 20.62 & 1.44 & 14.38 & 2.43 & 32.54 & 1.42 & 3.56 & 6.70 \\
\hline A. tuberculata & 30.56 & 2.18 & 2.26 & 6.14 & 19.17 & 4.62 & 10.57 & 14.23 & 10.27 \\
\hline S. calospora & 15.16 & 8.46 & 10.32 & 9.64 & 8.57 & 10.49 & 12.17 & 11.63 & 13.55 \\
\hline Scutellospora sp1 & 31.32 & 1.67 & 4.49 & 0.98 & 1.69 & 2.28 & 10.92 & 13.57 & 33.08 \\
\hline Acaulospora sp1 & 15.29 & 8.54 & 20.89 & 2.01 & 16.79 & 15.49 & 11.74 & 5.88 & 3.38 \\
\hline Acaulospora sp2 & 19.93 & 2.58 & 7.64 & 8.75 & 3.51 & 2.29 & 6.86 & 42.39 & 6.05 \\
\hline Acaulospora sp3 & 40.55 & 1.36 & 0.64 & 8.12 & 14.14 & 3.81 & 3.25 & 17.93 & 10.20 \\
\hline Glomus sp1 & 49.88 & 1.29 & 8.51 & 11.94 & 11.69 & 1.12 & 3.35 & 1.58 & 10.64 \\
\hline Glomus sp2 & 11.24 & 7.04 & 3.37 & 24.53 & 2.06 & 28.82 & 2.94 & 11.29 & 8.71 \\
\hline Glomus sp3 & 45.61 & 6.64 & 8.13 & 7.94 & 3.87 & 0.56 & 1.09 & 0.98 & 25.17 \\
\hline Glomus sp4 & 50.81 & 8.58 & 10.79 & 5.28 & 9.10 & 4.67 & 1.19 & 1.42 & 8.16 \\
\hline
\end{tabular}

Bold numbers indicate the environmental attributes that most explained a given response variable. aVariability of individual species of AMF was based on spores abundance. S (Sulfur), Iron (Fe), Boro (B), P (Phosphorus), Org-C (Organic carbon), Cation exchange capacity (CEC), Clay content (Clay).

however, phytophysiognomy, here represented by three distinct plant communities, was the explanatory variable that most shaped the AMF communities.

\section{Arbuscular mycorrhizal fungi in the soil}

Thirteen AMF morphospecies were found in the current study. Of these, five species (A. foveata, A. mellea, A. tuberculata, $R$. fasciculatum and S. calospora) were found in other studies on the Atlantic Forest (Jobim et al. 2018). The presence of the other eight morphospecies (three Acaulospora spp, four Glomus spp and one Scutellospora sp) could not be linked to other areas since they were not identified by species and might represent undescribed species.

The most abundant Glomeromycotina genus (Glomus) and the six most frequent species (Glomus sp. 1, Glomus sp. 3, A. mellea, Acaulospora sp1, Glomus sp4 and Glomus $\mathrm{sp2}$ ), corroborated previous findings on the prevalence of Glomus and Acaulospora in Atlantic Forest soils (Souchie et al. 2006; Stürmer et al. 2006; Moreira et al. 2007; Pereira et al. 2014; Bonfim et al. 2016). Given that our data was based on morphological identification of soil spores, real diversity in the field could indeed be greater (Varela-Cervero et al. 2015).

\section{Determining factors of the AMF community and root colonization}

Some authors state that soil features such as chemistry and texture are predominantly responsible for shaping the AMF community (Oehl et al. 2010; Bonfim et al. 2016; Sousa et al. 2018), while other authors suggest that AMF community structure is modified by vegetation and soil types (Pagano et al. 2013; Oehl et al. 2010; Lovelock et al. 2003). Unlike previous studies on the Atlantic Forest, we used PCA and HP analysis to quantify how phytophysiognomy and soil properties affect the variability of spore abundance, diversity indexes, AMF species and root colonization.

PCA indicated similarities and differences among the phytophysiognomies, and thus showed that phytophysiognomy affects the AMF community. Therefore, the three forest types were grouped separately. Specifically, the Restinga and Montane forests showed distinct AMF community, soil chemical and soil physical characteristics, while the Lowland forest showed intermediate AMF community composition and soil attributes that fit between the other two phytophysiognomies. The HP method was also used to quantify the individual contribution of the explanatory variables (set to a maximum of nine variables) for each response variable (Walsh \& Mac Nally 2015). HP 
demonstrated that the phytophysiognomy and texture (clay content) had a greater determining effect on AMF variables than did soil chemical attributes (Tab. 3). In addition to phytophysiognomy and clay content, $\mathrm{pH}$ explained the occurrence of one AMF species and root colonization; B explained two diversity variables; and P, S and CEC explained one AMF variable each.

\section{Contribution of phytophysiognomy on the determination of the AMF community}

Phytophysiognomy most explained variability in spore density and five of the $13 \mathrm{AMF}$ species (Tab. 3). Furthermore, variability in the most frequent AMF species (Glomus sp. 1, Glomus sp. 3, Glomus sp4 and Glomus sp2) was better explained by phytophysiognomy than by soil physical and chemical properties. These Glomus species were mainly associated with the Restinga forest. Interestingly, the Restinga forest showed the lowest plant-species richness among the forest types studied (Assis et al. 2011; Campos et al. 2011; Padgurschi et al. 2011); but had higher pH, Zn and sand content (Tab. 1). Some of these findings have already been reported: the adaptation of Glomus to different $\mathrm{pH}$ ranges (Coughlan et al. 2000) and greater abundance of Glomus sp. spores with higher soil Zn content (MontielRozas et al. 2017; Silva et al. 2014). However, contrary to Lekberg et al. (2007), we found that Glomus species were positively associated to soils with greater sand content.

Conversely, some authors have suggested that the plant community may alter soil characteristics that consequently affect the abundance of Glomus species (Lovelock et al. 2003; Mathimaran et al. 2005). Similarly, we found that plant community is the most important factor explaining variation in Glomus species.

\section{Contribution of individual soil properties on determining AMF community and root colonization}

Besides phytophysiognomy, physical and chemical soil properties also explained some of the variability in spore abundance, diversity variables and root colonization. After phytophysiognomy, clay content was the second most significant factor explaining variation in AMF species (three of the 13 AMF species: two Scutellospora species (S. calospora and Scutellospora sp1) and Glomus sp2).

Some authors have reported that vegetation type and soil texture have a greater influence on AMF community than soil chemical properties (Lovelock et al. 2003; Mathimaran et al. 2005; Silva et al. 2015a; Sousa et al. 2018). However, other studies have found that while soil chemistry and vegetation type do modify AMF communities, soil texture does not (Pagano et al. 2013; Gomide et al. 2014). Yet another study has shown that management, plant community, soil iron and fine sand influence AM fungal communities in protected and sustainably managed areas of the Atlantic Forest (Pereira et al. 2018). Nevertheless, recognizing the effect of clay content on the occurrence of an individual species can contribute to a better understanding of that species' ecology.

Soil $\mathrm{pH}$ best explained variation in A. foveata. Although this was a positive association, all the soils in the current study were very acidic ( $\mathrm{pH}$ of 4.17 - 4.50), which generally favors A. foveata sporulation (Klironomos et al. 1993; Moutoglis \& Widden 1996). Therefore, this limited $\mathrm{pH}$ range could have influenced competition among AMF species and determined sporulation.

Phosphorus was positively associated with and most explained variation in A. mellea. Spore densities of some AMF species increase when low levels of phosphorus are applied, relative to no $\mathrm{P}$ applications (Mårtensson \& Carlgren 1994; Kahiluoto et al. 2001).

Boron content was positively associated with and best explained variations in richness and estimated richness (ACE-1). Boron is not essential for microorganism growth (except for some cyanobacteria), but may affect microbial processes (e.g., quorum sensing and antibiotic production) (Bonilla et al. 1990; Semmelhack et al. 2004). However, further study is needed to understand how B content affects AMF communities.

Evenness was better explained by CEC than by phytophysiognomy and the other physicochemical properties. CEC was negatively associated with evenness but positively associated with organic carbon and $\mathrm{pH}$. According to the theory of reciprocally-regulated resource exchange between AM fungi and plants (Walder \& Heijden 2015), we hypothesized that higher CEC would favor more efficient AMF species that deliver more cationic nutrients to the plants. The plants, in turn, would favor these more efficient fungi, resulting in their dominance.

Root colonization variability was most determined by soil $\mathrm{pH}$. The role of $\mathrm{pH}$ in mycorrhizal colonization is not well understood but it has been reported that increasing the $\mathrm{pH}$ of acidic soil improves root colonization (Siqueira et al. 1984; Clark 1997; Coughlan et al. 2000). Furthermore, pH seems to have distinct effects on root colonization given different AMF isolates (Medeiros et al. 1994).

\section{Final considerations}

Bonfim et al. (2016) also used AMF diversity to distinguish three areas at different altitudes in the Atlantic Forest. We broadened this scope by also determining to what extent phytophysiognomy, physical and chemical variables explained variation in AMF species, diversity and root colonization.

Other studies have shown that AM spores and colonization are influenced by the succession/restoration stage of the Atlantic Forest, but in non-mature and nonnative phytophysiognomies (Stürmer et al. 2006; Zangaro et al. 2013). In protected and sustainably managed areas of Atlantic Forest, the management, plant community and 


\section{Lorrane Marques Duarte, Simone Cristina Braga Bertini, Sidney Luiz Stürmer, Marcio Rodrigues Lambais and Lucas Carvalho Basilio Azevedo}

soil iron and fine sand was found as factors influencing AM fungal communities (Pereira et al. 2018). Nevertheless, as in our study, relationships between AMF community structure and plant community have also been shown in land-use types and biomes other than those of the Atlantic Forest (Davison et al. 2011; Gomide et al. 2014; Johnson et al. 1992; Mueller et al. 2014). Thus, our study expands on this research by showing that variations in AMF indices and species are best explained by phytophysiognomy, followed by soil texture and then soil chemical characteristics.

We were able to add to current AMF research by using HP. To the best of our knowledge, this is the first time HP has been used to evaluate AMF community data. HP is a common statistical technique in animal ecology and water quality studies (Heikkinen et al. 2005; Varanka \& Luoto 2012), but recently, its usefulness has been demonstrated in soil ecology studies (Bertini et al. 2014). Our study shows the potential of HP for analyzing ecological data of an AMF community in a tropical rain forest.

Despite differences in AMF species composition among different phytophysiognomies, AMF diversity and root colonization remained the same throughout the three phytophysiognomies. Given that we collected our soil and root samples only once at the beginning of the wet season, we were unable to estimate the effect of season on the AMF community. On the other hand, Pereira et al (2018) found that season did not affect AMF community structure. Nevertheless, our findings expand on our understanding of the factors that determine AMF communities in the Atlantic Forest and contribute to the AM database for this environment, which may in turn be useful in future comparisons.

\section{Acknowledgements}

The authors thank the Fundação de Amparo à Pesquisa do Estado de São Paulo (FAPESP) for financial support. SLS and MRL thank the Conselho Nacional de Desenvolvimento Científico e Tecnológico (CNPq, Brazil) for a Research Assistantship. LMD thanks the Conselho Nacional de Desenvolvimento Científico e Tecnológico ( $\mathrm{CNPq})$ and the Universidade Federal de Uberlândia for granting an undergraduate scholarship. Thanks to the staff of the Molecular Microbiology Lab at ESALQ, Universidade de São Paulo, specially to PhD. Sandra Patricia Montenegro Gomez.

\section{References}

Antunes PM, Koch AM, Morton JB, Rillig MC, Klironomos JN. 2011. Evidence for functional divergence in arbuscular mycorrhizal fungi from contrasting climatic origins. New Phytolologist 189: 507-514.

Arenas F, Sánchez I, Hawkins SJ, Jenkins SR. 2006. The invasibility of marine algal assemblages: role of functional diversity and identity. Ecology 87: 28512861.
Assis MA, Prata EMB, Pedroni F, et al. 2011. Florestas de restinga e de terras baixas na planície costeira do sudeste do Brasil: vegetação e heterogeneidade ambiental. Biota Neotropica 11: 103-121.

Bertini SCB, Azevedo LCB, Mendes IC, Cardoso EJBN. 2014. Hierarchical partitioning for selection of microbial and chemical indicators of soil quality. Pedobiologia 57: 293-301.

Bonfim JA, Vasconcellos RLF, Gumiere T, Mescolotti DDLC, Oehl F, Cardoso EJBN. 2016. Diversity of arbuscular mycorrhizal fungi in a Brazilian Atlantic Forest toposequence. Microbial Ecology 71: 164-177.

Bonilla I, Garcia-Gonzalez M, Mateo P. 1990. Boron requirement in cyanobacteria: its possible role in the early evolution of photosynthetic organisms. Plant Physiology 94: 1554-1560.

Campos MCRD, Tamashiro JY, Assis MA, Joly CA. 2011. Florística e fitossociologia do componente arbóreo da transição Floresta Ombrófila Densa das Terras Baixas-Floresta Ombrófila Densa Submontana do Núcleo Picinguaba/PESM, Ubatuba, sudeste do Brasil. Biota Neotropica 11: 301-312

Chao A. 1984. Nonparametric estimation of the number of classes in a population. Scandinavian Journal of Statistics 11: 265-270.

Chao A, Lee SM. 1992. Estimating the number of classes via sample coverage. Journal of the American Statistical Association 87: 210-217.

Chao A, Shen TJ. 2010. Program SPADE (Species Prediction And Diversity Estimation). Program and user's guide. Hsinchu, National Tsing Hua University, Taiwan. http://chao.stat.nthu.edu.tw

Chevan A, Sutherland M. 1991. Hierarchical partitioning. The American Statistician 45: 90-96.

Clark RB. 1997. Arbuscular mycorrhizal adaptation, spore germination, root colonization, and host plant growth and mineral acquisition at low pH. Plant and Soil 192: 15-22.

Coughlan AP, Dalpé Y, Lapointe L, Piché Y. 2000. Soil pH-induced changes in root colonization, diversity, and reproduction of symbiotic arbuscular mycorrhizal fungi from healthy and declining maple forests. Canadian Journal of Forest Research 30: 1543-1554.

Davison J, Öpik M, Daniell TJ, Moora M, Zobel M. 2011. Arbuscular mycorrhizal fungal communities in plant roots are not random assemblages. FEMS Microbiology Ecology 78: 103-115.

Embrapa. 2009. Banco de dados climáticos do Brasil. Brasília, Embrapa. http://www.bdclima.cnpm.embrapa.br/

Gee GW, Or D. 2002. Particle-size analysis. In: Dane JH, Topp CG. (eds.) Methods of soil analysis: part 4 physical methods. SSSA Book Series. Vol 5.4. Madison, Soil Science Society of America. p. 255-293.

Gerdemann JW, Nicolson TH. 1963. Spores of mycorrhizal Endogone species extracted from soil by wet sieving and decanting. Transactions of the British Mycological Society 46: 235-244.

Giovannetti M, Mosse B. 1980. An evaluation of techiniques for measuring vesicular arbuscular mycorrhizal infecion in roots. New Phytologist 84: 489-500

Gomide PHO, Silva MLN, Soares CRFS, et al. 2014. Fungos micorrízicos arbusculares em fitofisionomias do Pantanal da Nhecolândia, Mato Grosso do Sul. Revista Brasileira de Ciência do Solo 38: 1114-1127.

Heijden MGA, Boller T, Wiemken A, Sanders IR. 1998. Different arbuscular mycorrhizal fungi species are potential determinants of plant community structure. Ecology 79: 2082-2091.

Heikkinen RK, Luoto M, Kuussaari M, Pöyry J. 2005. New insights into butterfly environment relationships using partitioning methods. Proceedings of the Royal Society of London B: Biological Sciences 272: 2203-2210.

Jobim K, Vista XM, Goto BT. 2018. Updates on the knowledge of arbuscular mycorrhizal fungi (Glomeromycotina) in the Atlantic Forest biome-an example of very high species richness in Brazilian biomes. Mycotaxon 133: 209-209.

Johnson NC, Tilman D, Wedin D. 1992. Plant and soil controls on mycorrhizal fungal communities. Ecology 73: 2034-2042.

Joly CA, Assis MA, Bernacci LC, et al. 2012. Florística e fitossociologia em parcelas permanentes da Mata Atlântica do sudeste do Brasil ao longo de um gradiente altitudinal. Biota Neotropica 12: 123-145.

Kahiluoto H, Ketoja E, Vestberg M, Saarela I. 2001. Promotion of AM utilization through reduced P fertilization 2. Field studies. Plant and Soil 231: 65-79. 


\section{Arbuscular mycorrhizal fungal communities in soils under three phytophysiognomies of the Brazilian Atlantic Forest}

Klironomos JN, Moutoglis P, Kendrick W, Widden P. 1993. A comparison of spatial heterogeneity of vesicular-arbuscular mycorrhizal fungi in two maple-forest soils. Canadian Journal of Botany 71: $1472-1480$.

Klironomos JN, Zobel M, Tibbett M, et al. 2011. Forces that structure plant communities: quantifying the importance of the mycorrhizal symbiosis. New Phytologist 189: 366-370.

König S, Wubet T, Dormann CF, Hempel S, Renker C, Buscot F. 2010. TaqMan real-time PCR assays to assess arbuscular mycorrhizal responses to field manipulation of grassland biodiversity: effects of soil characteristics, plant species richness, and functional traits. Applied and Environmental Microbiology 76: 3765-3775.

Lambais MR, Lucheta AR, Crowley DE. 2014. Bacterial community assemblages associated with the phyllosphere, dermosphere, and rhizosphere of tree species of the Atlantic Forest are host taxon dependent. Microbial Ecology 68: 567-574.

Lekberg Y, Koide RT, Rohr JR, Aldrich-Wolfe L, Morton JB. 2007. Role of niche restrictions and dispersal in the composition of arbuscular mycorrhizal fungal communities. Journal of Ecology 95: 95-105.

León DG, Moora M, Öpik M, et al. 2016. Symbiont dynamics during ecosystem succession: co-occurring plant and arbuscular mycorrhizal fungal communities. FEMS Microbiology Ecology 92: 7.

León DG, Neuenkamp L, Moora M, et al. 2018. Arbuscular mycorrhizal fungal communities in tropical rain forest are resilient to slash-andburn agriculture. Journal of Tropical Ecology 34: 186-199.

Lepš J, Šmilauer P. 2003. Multivariate analysis of ecological data using CANOCO. 1st. edn. New York, Cambridge University Press.

Littell RC, Milliken GA, Stroup WW, Wolfinger RD, Schabenberber O. 2006. SAS for Mixed Models. 2nd. edn. Cary, SAS Institute Inc.

Lovelock CE, Andersen K, Morton JB. 2003. Arbuscular mycorrhizal communities in tropical forests are affected by host tree species and environment. Oecologia 135: 268-279.

Mac Nally R. 2000. Regression and model building in conservation biology, biogeography and ecology: The distinction between and reconciliation of 'predictive' and 'explanatory' models. Biodiversity \& Conservation 9: 655-671.

Mac Nally R, Walsh CJ. 2004. Hierarchical partitioning public domain software. Biodiversity \& Conservation 13: 659-660.

Magurran AE. 1988. Ecological diversity and its measurement. Princenton, Princenton University Press.

Mårtensson AM, Carlgren K. 1994. Impact of phosphorus fertilization on VAM diaspores in two Swedish long-term field experiment. Agriculture, Ecosystems \& Environment 47: 327-334.

Mathimaran N, Ruh R, Vullioud P, Frossard E, Jansa J. 2005. Glomus intraradices dominates arbuscular mycorrhizal communities in a heavy textured agricultural soil. Mycorrhiza 16: 61-66.

Medeiros CAB, Clark RB, Ellis JR. 1994. Growth and nutrient uptake of sorghum cultivated with vesicular-arbuscular mycorrhiza isolates at varying $\mathrm{pH}$. Mycorrhiza 4: 185-191.

Millington JDA, Perry GLW, Romero-Calcerrada R. 2007. Regression techniques for examining land use/cover change: a case study of a Mediterranean landscape. Ecosystems 10: 562-578.

Mittermeier RA, Myers N, Thomsen JB, Fonseca GA, Olivieri S. 1998. Biodiversity hotspots and major tropical wilderness areas: approaches to setting conservation priorities. Conservation Biology 12: 516-520.

Montgomery DC, Peck EA. 1992. Introduction to linear regression analysis. 2nd. edn. New York, Wiley.

Montiel-Rozas MM, López-García Á, Madejón P, Madejón E. 2017. Native soil organic matter as a decisive factor to determine the arbuscular mycorrhizal fungal community structure in contaminated soils. Biology and Fertility of Soils 53: 327-338.

Moreira M, Baretta D, Tsai SM, Gomes-da-Costa SM, Cardoso EJBN. 2007. Biodiversity and distribution of arbuscular mycorrhizal fungi in Araucaria angustifolia forest. Scientia Agricola 64: 393-399.

Morellato LPC, Haddad CF. 2000. Introduction: The Brazilian Atlantic Forest. Biotropica 32: 786-792.

Moutoglis P, Widden P. 1996. Vesicular-arbuscular mycorrhizal spore populations in sugar maple (Acer saccharum marsh. L.) forests. Mycorrhiza 6: 91-97.
Mueller RC, Paula FS, Mirza BS, Rodrigues JL, Nüsslein K, Bohannan BJ. 2014. Links between plant and fungal communities across a deforestation chronosequence in the Amazon rainforest. The ISME Journal 8: 1548-1550.

Mummey DL, Rillig MC. 2006. The invasive plant species Centaurea maculosa alters arbuscular mycorrhizal fungal communities in the field. Plant and Soil 288: 81-90.

Myers N, Mittermeier RA, Mittermeier CG, Fonseca GA, Kent J. 2000. Biodiversity hotspots for conservation priorities. Nature 403: 853-858.

Oehl F, Laczko E, Bogenrieder A, et al. 2010. Soil type and land use intensity determine the composition of arbuscular mycorrhizal fungal communities. Soil Biology and Biochemistry 42: 724-738.

Padgurschi MCG, Pereira LP, Tamashiro JY, Joly CA. 2011. Composição e similaridade florística entre duas áreas de Floresta Atlântica Montana, São Paulo, Brasil. Biota Neotropica 11: 139-152.

Pagano MC, Zandavalli RB, Araújo FS. 2013. Biodiversity of arbuscular mycorrhizas in three vegetational types from the semiarid of Ceará State, Brazil. Applied Soil Ecology 67: 37-46.

Pereira CMR, Silva DKA, Ferreira ACDA, Goto BT, Maia LC. 2014. Diversity of arbuscular mycorrhizal fungi in Atlantic forest areas under different land uses. Agriculture, Ecosystems \& Environment 185: 245-252.

Pereira CMR, Silva DKA, Goto BT, Rosendahl S, Maia LC. 2018. Management practices may lead to loss of arbuscular mycorrhizal fungal diversity in protected areas of the Brazilian Atlantic Forest. Fungal Ecology 34: 50-58.

Pont D, Hugueny B, Oberdorff T. 2005. Modelling habitat requirement of European fishes: Do species have similar responses to local and regional environmental constraints? Canadian Journal of Fisheries and Aquatic Sciences 62: 163-173.

R Development Core Team. 2017. A language and environment for statistical computing. Vienna, R Foundation for Statistical Computing.

Ribeiro MC, Metzger JP, Martensen AC, Ponzoni FJ, Hirota MM. 2009. The Brazilian Atlantic Forest: How much is left, and how is the remaining forest distributed? Implications for conservation. Biological Conservation 142: 1141-1153.

Rillig MC, Mummey DL. 2006. Mycorrhizas and soil structure. New Phytologist 171: 41-53.

Schenck NC, Pérez Y. 1990. Manual for identification of VA mycorrhizal fungi. 3rd. edn. Gainesville, Synergistic.

Semmelhack MF, Campagna SR, Hwa C, Federle MJ, Bassler BL. 2004. Boron binding with the quorum sensing signal AI-2 and analogues. Organic Letters 6: 2635-2637.

Setzer J. 1966. Atlas climatológico do estado de São Paulo. São Paulo, Comissão Interestadual da Bacia do Paraná-Paraguai.

Siegloch AE. 2010. Estrutura espacial das comunidades de Ephemeroptera HAECKEL, 1896 (Insecta) em riachos da Serra da Mantiqueira e da Serra do Mar, Estado de São Paulo. Msc Thesis, University of São Paulo, São Paulo.

Silva DKA, Souza RG, Velez BAA, Silva GA, Oehl F, Maia LC. 2015a. Communities of arbuscular mycorrhizal fungi on a vegetation gradient in tropical coastal dunes. Applied Soil Ecology 96: 7-17.

Silva DKA, Coutinho FP, Escobar IEC, et al. 2015b. The community of arbuscular mycorrhizal fungi in natural and revegetated coastal areas (Atlantic Forest) in northeastern Brazil. Biodiversity and Conservation 24: 2213-2226.

Silva FCDS. 2009. Manual de análises químicas de solos, plantas e fertilizantes. Embrapa Informação Tecnológica. Rio de Janeiro, Embrapa Solos.

Silva IR, Mello CMA, Neto RAF, et al. 2014. Diversity of arbuscular mycorrhizal fungi along an environmental gradient in the Brazilian semiarid. Applied Soil Ecology 84: 166-175.

Siqueira JO, Hubbell DH, Mahmud AW. 1984. Effect of liming on spore germination, germ tube growth and root colonization by vesiculararbuscular mycorrhizal fungi. Plant and Soil 76: 115-124.

Smith SE, Read DJ. 2008. Mycorrhizal symbiosis. 3rd. edn. New York, Academic Press. 


\section{Lorrane Marques Duarte, Simone Cristina Braga Bertini, Sidney Luiz Stürmer, Marcio Rodrigues Lambais and Lucas Carvalho Basilio Azevedo}

Souchie EL, Saggin-Júnior OJ, Silva EM, Campello EF, Azcón R, Barea JM. 2006. Communities of P-solubilizing bacteria, fungi and arbuscular mycorrhizal fungi in grass pasture and secondary forest of Paraty, RJ-Brazil. Anais da Academia Brasileira de Ciências 78: 183-193.

Sousa NM, Veresoglou SD, Oehl F, Rillig MC, Maia LC. 2018. Predictors of arbuscular mycorrhizal fungal communities in the Brazilian tropical dry forest. Microbial Ecology 75: 447-458.

Spatafora JW, Chang Y, Benny GL, et al. 2016. A phylum-level phylogenetic classification of zygomycete fungi based on genome-scale data. Mycologia 108: 1028-1046.

Stürmer SL, Klauberg-Filho O, Queiroz MHD, Mendonça MMD. 2006. Occurrence of arbuscular mycorrhizal fungi in soils of early stages of a secondary succession of Atlantic Forest in South Brazil. Acta Botanica Brasilica 20: 513-521.

Varanka S, Luoto M. 2012. Environmental determinants of water quality in boreal rivers based on partitioning methods. River Research and Applications 28: 1034-1046.
Varela-Cervero S, Vasar M, Davison J, Barea JM, Öpik M, Azcón-Aguilar C. 2015. The composition of arbuscular mycorrhizal fungal communities differs among the roots, spores and extraradical mycelia associated with five Mediterranean plant species. Environmental Microbiology 17: 2882-2895

Vierheilig H, Coughlan AP, Wyss U, Piché Y. 1998. Ink and vinegar, a simple staining technique for arbuscular-mycorrhizal fungi. Applied and Environmental Microbiology 64: 5004-5007.

Walder F, Heijden MGA. 2015. Regulation of resource exchange in the arbuscular mycorrhizal symbiosis. Nature Plants 1: 15159. doi: 10.1038/nplants.2015.159

Walsh C, Mac Nally R. 2015. Package 'hier. part'. R package version 1.0-4. Vienna, R Foundation for Statistical Computing.

Zangaro W, Rostirola LV, Souza PB, et al. 2013. Root colonization and spore abundance of arbuscular mycorrhizal fungi in distinct successional stages from an Atlantic rainforest biome in southern Brazil. Mycorrhiza 23: 221-233. 